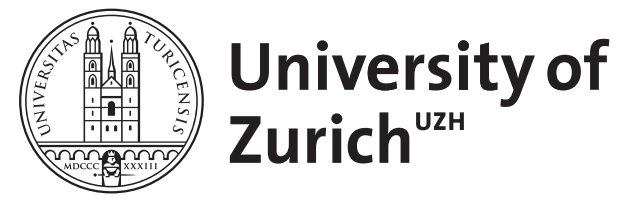

Zurich Open Repository and Archive

University of Zurich

University Library

Strickhofstrasse 39

CH-8057 Zurich

www.zora.uzh.ch

Year: 2017

\title{
How to measure narrativity? : notes on some problems with comparing degrees of narrativity across different media
}

\author{
Brütsch, Matthias
}

Posted at the Zurich Open Repository and Archive, University of Zurich

ZORA URL: https://doi.org/10.5167/uzh-144872

Book Section

Published Version

Originally published at:

Brütsch, Matthias (2017). How to measure narrativity? : notes on some problems with comparing degrees of narrativity across different media. In: Hansen, Per Krogh; Pier, John; Roussin, Philippe; Schmid, Wolf. Emerging vectors of narratology. Berlin: De Gruyter, 315-344. 
Matthias Brütsch (Zurich)

\section{How to Measure Narrativity?}

Notes on Some Problems with Comparing

Degrees of Narrativity Across Different Media

\section{Introduction}

Besides analysing structural principles of narrative works, narratologists such as Gerald Prince (1982, 1996, 1999, 2008), Seymour Chatman (1978, 1990) and MarieLaure Ryan $(2004,2007)$ have repeatedly tried to grasp the essential characteristics of narration, either by sketching prototypes or by defining its basic elements (narremes). ${ }^{1}$ Their methodologies include distinguishing narrative from non-narrative text types (description, argument, etc.) and, for the former, the postulation of varying degrees of narrativity. The growing trend within narratology to apply itself to different kinds of media has in recent years once again raised the question of how to define and qualify narration.

Comparing the narrativity of different texts within the same medium implies a focus on the narrated and how the story is structured by the discourse. In this context, verbal narratives are the privileged field of investigation and factors such as eventfulness, tellability or coherence of the story world become important criteria for measuring narrativity. On the other hand, comparing the manifestation of narrativity in different media-the central topic of this paper-implies a focus on the way the story is presented and on questions of mediacy and narrative agency.

In what follows I will first try to classify different transmedial comparisons according to their criteria for evaluating narrativity and according to the results yielded by such comparison. My second step will be to scrutinize the arguments put forward and to question those views which in my mind are problematic. I shall focus solely on literature, film and drama, although other media such as comics or pantomime, which use pictures or live-performances as well, might

1 A German version of this article appeared in Diegesis (Brütsch 2013a). I would like to thank Michael Scheffel, Guido Kirsten and the participants of the workshop "film narratology" at the University of Zurich in March 2013 for comments and suggestions as well as Henry M. Taylor for the revision of the English version. 
also be included in the discussion. In order to illustrate and substantiate my critical assessment, I will on several occasions refer to the specific (and exceptional) case of backward narration, which will serve as a test case for some of my claims. As a theoretical framework, I will use Wolf Schmid's model of narrative constitution, which is also a useful starting point for redefining the concept of narration.

\section{Telling versus Showing}

The term narrativity only started to gain prominence in the mid-1960s. ${ }^{2}$ But the question as to which media can be used to tell stories and which cannot (or only to a lesser degree) was posed well before this, particularly in the German "Romantheorie" (theory of the novel) during the first half of the twentieth century. ${ }^{3}$ In this tradition, literary theorists such as Käte Friedemann, Käte Hamburger or Franz Stanzel emphasized differences between the novel and the play. The crucial factor for denying drama the status of a narrative art (and thus separating it from the novel) was its ostensible absence of mediacy:

[W] henever something is reported or narrated, there is a mediator-the voice of a narrator is audible. Earlier theories of the novel have already recognized this fact as a criterion to distinguish narrative from dramatic forms of art. (Stanzel 1995 [1979], 15; emphasis added, translation mine $)^{4}$

Stanzel's or Friedemann's foregrounding of the mediacy of the novel must be viewed against the backdrop of normative claims by scholars such as Friedrich Spielhagen (1967 [1883]) or Percy Lubbock (1924 [1921]) who stipulated objective forms of narration with a minimal or invisible presence of the narrator. In its most radical variant, this position claims that stories can be presented or "shown" without any mediation at all:

2 Interestingly enough, it was film theorist Christian Metz who introduced and first discussed the concept of narrativity in the mid-1960s in three texts (1968a [1964], 1968b [1966], 1968c [1966]) in which he already advocated a decidedly transmedial approach (cf. Gaudreault 1990). Surprisingly, these articles seem to be little known among narratologists with a background in literary theory, as Porter Abbott's entry "Narrativity" in the Handbook of Narratology (2014 [2009]) reveals, which despite covering the history of the concept does not mention any of them. 3 Cf. Schmid (2010 [2005], 1-2).

4 In the translation by Charlotte Goedsche the explicit reference to the play (which is important in our context) is omitted by rendering "dramatische Dichtung" as "other forms of literary art" (Stanzel 1986 [1979], 4). 
I speak of his "telling” the story, but of course he [the author] has no idea of doing that and no more; the art of fiction does not begin until the novelist thinks of his story as a matter to be shown, to be so exhibited that it will tell itself. (Lubbock 1924 [1921], 62; original emphasis)

The concern of Friedemann, Stanzel, Booth and others was to show that the alleged absence of the narrator in novels as championed by Lubbock is an illusion and that all novels are necessarily mediated by a narrator. In this context, the distinction between the mediated novel and the unmediated play appears as a by-product of an argument stressing a common feature of all novels, namely that whoever claims that novels can "show" or present their stories without mediation should, in order to become aware of the impossibility of this claim, consider the theatre, where stories really are presented in this fashion.

This approach can be found not only in the pre-structuralist theory of the novel, but also among representatives of the classical or structuralist phase of narratology, most prominently in the writings of Gerrard Genette. ${ }^{5}$ His exclusion of drama from the realm of narrative adheres to the same reasoning:

[T] he very idea of showing, like that of imitation or narrative representation (and even more so, because of its naively visual character), is completely illusory: in contrast to dramatic representation, no narrative can "show" or "imitate" the story it tells. (Genette 1980 [1972], 163-164; original emphasis)

Additionally, Genette defines narration as a "representation by the means of language" or "verbal transmission" (1966, 152; original emphasis, translation mine; cf. 1988 [1983], 16), thus explicitly limiting the narrative domain to stories conveyed by verbal language. Accordingly, he claims that not only drama, but also film, comic strips and romans-photo transmit their stories by an "extranarrative medium" (1988 [1983], 16).

5 Other scholars propounding this view are Prince (in the first edition of his Dictionary of Narratology, 1987) and Mahler (2001). 
Schematically, this position can be represented as follows:

\begin{tabular}{lllll}
\hline Position 1 & mediacy & $\begin{array}{l}\text { narrator } / \\
\text { narrative } \\
\text { instance }\end{array}$ & $\begin{array}{l}\text { mimesis / } \\
\text { imitation / } \\
\text { showing }\end{array}$ & > narrativity \\
\hline literature & yes & yes & no & > yes \\
\hline film & no & no & yes & $>$ no \\
\hline drama & no & no & yes & $>$ no \\
\hline
\end{tabular}

In this view, the different issues are closely related: mediacy and verbal discourse imply each other, just as mimesis/imitation/showing and visual/scenic representation. Conversely, verbal discourse and mimesis/imitation/showing (with the exception of the representation of dialogue) exclude each other, just as do visual/scenic representation and mediacy. Consequently, only a verbal narrator is qualified as a mediating (and thus narrative) instance or agency. ${ }^{6}$

\section{Narrow and Broad Definitions of Narrativity}

In more recent narratological publications by literary scholars, a second position emerges which adheres to the former except for one important point. Authors such as Ansgar and Vera Nünning (2002, 6-7), Wolf Schmid (2010 [2005], 1-7, 216217), Werner Wolf (2002) or Irina Rajewsky (2007) distinguish between narrativity in a narrow and in a broad sense. The criteria for the narrow definition are the same as the first position had established for narrativity as such: verbal transmission of the story, mediacy and presence of a narrator or narrative instance. Contrary to the former approach, film, drama or comic strips are considered as being narrative, albeit only in a broad sense. And there is still the assumption that in these media stories are presented without mediation by a narrative instance, as the following quotations show:

Media: Here a distinction has to be made between media which convey narrative content through the mediation of a narrative instance and are thus able to produce narrations, i. e., basically verbal, oral or written communication, and media which (as a general rule)

6 The positions of Claude Bremond (1964) and Roland Barthes (1966), who both consider nonverbal media as fully narrative, were exceptions at this time and have, as Ryan $(2004,1)$ puts it, "remained in theoretical hibernation for over forty years." 
present stories without such a narrative instance, i. e., plays, pictorial media, film, etc. (Wolf 2002, 39; translation mine)

Mediated narrative texts (= narrative texts in the narrower sense): The story is told by a narrator. Mimetic narrative texts [plays, films, comic strips, ballets, pantomimes, narrative paintings]: The story is portrayed without a mediating narrative authority. (Schmid 2010 [2005], 7)

The ostensible absence of mediation is the reason why film, theatre, comic strips, etc. are only accepted as narrative media with some reservations, or are granted lesser narrative potential (as in Wolf 2002, who assumes a downward gradient of narrativity from literature to the drama, film/comic strip and picture series). ${ }^{7}$

A schematic outline of the second position shows that its assumptions as to how film and drama "represent" their stories are the same as those of the first, the only difference being that the seemingly unmediated mimetic presentation is regarded as narrative in a broader sense.

\begin{tabular}{lllll}
\hline Position 2 & mediacy & $\begin{array}{l}\text { narrator } \\
\text { narrative } \\
\text { instance }\end{array}$ & $\begin{array}{l}\text { mimesis / } \\
\text { imitation / } \\
\text { showing }\end{array}$ & > narrativity \\
\hline literature & yes & yes & no (only dialogue) & > yes (narrow definition) \\
\hline film & no & no & yes & > yes (broad definition) \\
\hline drama & no & no & yes & > yes (broad definition) \\
\hline
\end{tabular}

\section{Differing Views on Film and Drama}

Theatre scholar Manfred Pfister and film scholars Markus Kuhn and Nina Heiß advocate a third position, which adheres to crucial points of the second approach (such as the distinction between narrow and broad definitions of narrativity, with literature assigned to the former and drama to the latter). These proponents, however, differ with respect to film, which is not seen as a purely mimetic medium without mediating agency, but as a narrative medium in the narrower sense outlined above:

7 In a more recent contribution to the question of narrativity in different media (2011), Wolf is more cautious on this issue than in his article from 2002, in which he explicitly proposes a "scalar between maximal and minimal narrativity of the works in question” (96). 
The flexibility and mobility of the camera makes it possible to disrupt the chronology of the story (as in the flashback technique), to stretch or concentrate time [...] and to change the perspective of the presentation. All these are features familiar to us from narrative texts. For, unlike dramatic texts, both film and narrative texts possess a "mediating communication system"-which is what makes such manipulations of time and space possible in the first place. Thus, the flexible and mobile camera functions as a mediating communication system, fulfilling a narrative function that corresponds to the fictional narrator [...] in narrative texts. The film audience, like the readers of a narrative text, is not confronted directly with the material presented, as is the audience in the theatre, but indirectly, via the selective, accentuating and structuring medium of the camera or narrator. (Pfister 1991 [1977], 24-25)

Represented in our table, this position appears as follows:

\begin{tabular}{lllll}
\hline Position 3a & mediacy & $\begin{array}{l}\text { narrator / } \\
\text { narrative instance }\end{array}$ & $\begin{array}{l}\text { mimesis / } \\
\text { imitation / } \\
\text { showing }\end{array}$ & > narrativity \\
\hline literature & yes & yes & no (only dialogue) & > yes (narrow def.) \\
\hline film & yes & yes & no / only partly & > yes (narrow def.) \\
\hline drama & no / only partly & no / only partly & yes & > yes (broad def.) \\
\hline
\end{tabular}

Seymour Chatman goes one step further than position 3a in assigning narrativity to nonverbal (or more precisely: not exclusively verbal) media by asserting that all stories are necessarily mediated by a narrative instance, not only those conveyed by literary or filmic means, but also those performed on stage, the only difference being that in the latter two cases this instance is not personal, but impersonal:

Once we decide to define Narrative as the composite of story and discourse (on the basis of its unique double chronology), then logically, at least, narratives can be said to be actualizable on the stage or in other iconic media. [...] I would argue that every narrative is by definition narrated-that is, narratively presented-and that narration, narrative presentation, entails an agent even when the agent bears no signs of human personality. (Chatman 1990, 114-115; original emphasis) ${ }^{8}$

8 In Story and Discourse (1978), Chatman still argued for the existence of "nonnarrated stories" (or, as he himself contends, "minimally narrated stories"; 146-147). However, the opposition between nonnarrated (or minimally narrated) and narrated stories is not related to the medium of transmission, but to the perceptibility of the narrative agency, which may be more or less overt in any narrative medium. To claim that Chatman excludes nonverbal presentations from the realm of narrative, as Ryan $(2005,2)$ does, is a misinterpretation which disregards that already in Story 
Nevertheless, and contrary to Kuhn and Pfister, Chatman sticks to the idea that not only drama but also film belongs to the mimetic mode, and that both media can only be regarded as narrative in a broad sense $(1990,111,115) .^{9}$

\begin{tabular}{|c|c|c|c|c|}
\hline Position 3b & mediacy & $\begin{array}{l}\text { narrator / } \\
\text { narrative instance }\end{array}$ & $\begin{array}{l}\text { mimesis / } \\
\text { imitation / } \\
\text { showing }\end{array}$ & > narrativity \\
\hline literature & yes & yes & no & $>$ yes (narrow def.) \\
\hline film & yes & yes & yes & > yes (broad def.) \\
\hline drama & yes & yes & yes & > yes (broad def.) \\
\hline
\end{tabular}

A fifth position (which is number 4 in my counting, since $3 a$ and $b$ appear roughly equal) assumes a narrative instance for literature, film and drama and questions the exclusive assignment to the mimetic mode not only of film, but also of drama. In this view, put forward with minor variations by authors such as Albert Laffay (1948, 1964), Christian Metz (1968a [1964], 1968b [1966], 1968c [1966]), André Gaudreault (1988), A. Gaudreault and Francois Jost (1990), Manfred Jahn (2001), Brian Richardson (2007), Jan Alber and Monika Fludernik (2014 [2009]), there is no difference between literature, film and drama as regards their degree of narrativity.

\begin{tabular}{lllll}
\hline Position $\mathbf{4}$ & mediacy & $\begin{array}{l}\text { narrator / } \\
\text { narrative instance }\end{array}$ & $\begin{array}{l}\text { mimesis / } \\
\text { imitation / } \\
\text { showing }\end{array}$ & > narrativity \\
\hline literature & yes & yes & no & $>$ yes (narrow def.) \\
\hline film & yes & yes & no / only partly & $>$ yes (narrow def.) \\
\hline drama & yes & yes & no / only partly & $>$ yes (narrow def.) \\
\hline
\end{tabular}

and Discourse "narrator" is conceptualised as an instance which can be both personal (as in literature) and impersonal (as in film).

9 However, the opposition "diegetic" versus "mimetic texts" does not correspond to the opposition "recounting [...] with the mediation of a narrator" versus "without a mediation," as Schmid (2010 [2005], 7) claims, since for Chatman $(1990,115)$ the latter are no less mediated by narrative agency than the former. 


\section{Discourse- and Story-Oriented Definitions}

So far I have only taken into consideration positions which define narrativity with respect to characteristics of the narrative communication or the mode of representation. Such discourse-oriented definitions can be distinguished from story-oriented definitions which focus on aspects of the narrated and not the narrating (cf. Gaudreault 1988, 33-36; Schmid 2010 [2005], 1-2; Kuhn 2012, 64-70). Story-oriented definitions, especially of the minimalist kind such as "representation of a single event" (proposed by Genette 1966, 1; 1988 [1983], 18-20) or of two connected events (proposed by Prince 1982, 4), even if not totally media-unspecific, usually conceive of narrativity as a transmedial phenomenon. Nevertheless, authors using story-oriented definitions cannot simply be assigned to position 4, since a closer inspection of their writings quickly reveals that in their definitions the transmedial openness at the level of story is usually constrained by additions pertaining to discourse. We have already seen that for Genette the representation of events is narrative only if verbal transmission is involved, and for Prince solely if a personal narrator is present (at any rate in his dictionary entry of 1987). Even Marie-Laure Ryan, who explicitly promotes a media-independent definition of narrativity, brings the mode of representation back into play as soon as the question arises as to which medium has the greatest narrative potential. And despite beginning with the premise that language-centred approaches have to be overcome, she concludes with reference to the "overwhelming storytelling superiority of language" (Ryan 2014 [2009], 483) that literature is the "unmarked, standard manifestation" and "the fullest form of narrativity" (Ryan 2004, 13, 35). This view is closer to positions 2 and 3 (which distinguish between narrativity in a narrow and a broad sense) than to position 4 (which does not make this distinction).

Before I evaluate the different positions, let me add a few words on the historical dimension of my overview. It seems to me that within literary and theatre studies, a shift from position 1 to positions 2, 3 and 4 has taken place. Position 1 was strongly held in the phase of pre-structuralist and early structuralist narratology but has then been largely (though not completely) replaced by positions 2 and 3, which in turn have come under some pressure in recent years from position 4. Concerning the three media in question, it seems that film has been granted the status of a narrative art form (in a broad and partly also narrow sense) earlier than drama, which only recently has become the serious object of narratological study. This historical outline is of course very much simplified and only applies to literary and theatre studies. In film theory, positions 3 and 4 have been promoted by authors such as Albert Laffay, Christian Metz and André Gaudreault as early as the 1940s, 1960s and 1980s, respectively. In the following I will analyse the 
different positions not in terms of their historical context, but with respect to their logical consistency and rigour of argument.

\section{Mediacy}

As shown in the outline above, there is a broad consensus among theorists as to what is crucial for establishing narrativity in the narrow sense: mediacy, the existence of a narrator or narrative instance and the absence (or minor presence) of the mimetic mode. Positions 1 to 4 only differ as to whether film and drama fulfil these conditions wholly, in part or not at all. I shall therefore focus on these three issues which, as already noted, are closely related.

Let us begin with mediacy and related quotations from advocates of positions 1 and 2:

An event is "real," in a dramatic sense, if it happens right now, if we are witnessing it and experiencing its progress into the future. In an epic sense, on the other hand, the narrated event is not "real" at all, but only the telling itself. (Friedemann 1910, 25; translation mine)

A dramatic performance representing events does not constitute a narrative since these events, rather than being recounted, occur directly on stage. (Prince 1987, 58)

[I]n drama, the story is not told, it unfolds in front of our eyes. (Todorov 1966, 144; translation mine)

According to these statements, in the theatre we are directly confronted with the fictional events and characters of the story, whereas when reading a novel, these same elements are conveyed to us indirectly, mediated by the verbal telling of a narrator. Against this account, I would argue that the story (and all fictional characters and events comprised in it) merely exist as a mental representation. The story only comes to life in the imagination of the readers or spectators, no matter whether the work prompting this imagination is a book, a play or a movie. There are neither fictional characters nor fictional locations on stage, but actors and a stage scenery. In the cinema, there is even a double mediation, since all we are confronted with is images and sounds-again not of fictional characters and objects, but of actors, costumes and props. What is displayed on stage and screen are representations and not their fictional referents.

Against this objection, it has been argued that the absence of mediation in film and drama, as called into play by proponents of positions 1 and 2, does not refer to this very basic mediacy or mediality, but to a higher level that Irina Rajewsky calls "gestaltete Mittelbarkeit" and which implies an organizing or arranging 
principle beyond the simple fact of all media contents being necessarily mediated. Even if one agrees with this, positions 1 and 2 remain problematic, since they assume that this higher level mediacy may only be accomplished through personal mediators using verbal language.

That this is not the case can easily be demonstrated-for instance, by considering backward narrations. There are a few novels, but also some plays and films, that reverse the order in which the episodes of the story are presented. Christopher Homm by C. H. Sisson (1965) is a literary example, whereas Betrayal by Harold Pinter (1978) and its adaptation by David Jones (GB 1983) are theatrical and filmic examples. ${ }^{10}$ In all three instances, the story is conveyed backwards and thus mediated in a special way. However, this kind of mediation is not directly related to the basic mediality in the sense mentioned above (which is to say the verbal, audiovisual or live-performance nature of the representation) but depends on compositional techniques of a higher order which are quite similar in the three media, even if only in one case a verbal narrator is responsible for the effect. As to mediacy, backward narrations are no exception, providing instead good examples that film and drama in general mediate their stories no less than does literature, even if one takes mediacy to involve more than just the shaping force of each medium's means of expression.

\section{Diegesis and Mimesis}

Let us turn to the issue of the narrator or narrating instance. All the positions I have outlined begin with the premise that mediacy and narrative instance imply one another. However, position 1 assumes that there can be stories without corresponding narrations, and positions 2 and $3 a$ that there are narrations (in the broad sense) without corresponding narrative instances. What are the arguments of the respective authors? This question cannot be answered without also taking into account the third aspect outlined at the very beginning, namely the distinction between mimetic and diegetic modes of representation, since the argument effectively boils down to the claim that stories cannot only be narrated but also "shown" or "imitated." Position 1 contends that in these cases there is no narration, while positions 2 and 3a still speak of narration in a broad sense, but not of mediation by a narrative instance.

10 On backward narration in film, television series and literature, see Brütsch (2013b). 
Against position 1 I would argue that already the terms used to distinguish verbal narration and audiovisual representation are problematic, since, according to dictionaries and to common understanding, verbal accounts of events can just as well be called representations as audio-visual renderings can (especially in German and French). Speaking of fictional events, it is preferable to use the word presentation instead of representation anyway, which is even less suited to distinguish between the two.

The opposition between narration and imitation or between narration and showing is no less problematic. In this context, the terms usually referred to are diegesis and mimesis, as introduced by Plato in The Republic (ca. 370 BC). According to Plato, we must distinguish between those occasions where the poet speaks in his own voice and those instances where he speaks through the voices of his characters. However, as André Gaudreault has shown in a detailed analysis (1988, 53-70), these two ways of speaking are not equated by the ancient philosopher with diegesis and mimesis. Plato does not oppose these two concepts, but rather three forms of diegesis, one without any mimetic elements (lyrical poetry), one with some mimetic elements (epos) and one based completely on the mimetic mode (drama and comedy). In Plato's view, the latter, though heavily dependent on imitation, is no less a form of diegesis and thus narration than the former two. Moreover, Plato does not assume that the characters speak directly to us, since even when the poet tries to give this impression, it is of course still he who speaks. And to speak is to be taken quite literally here, since in Plato's time, not only drama and comedy, but also the epos and lyrical poetry were performed in front of live audiences. ${ }^{11}$

Thus Plato's conception does not substantiate the claim that the mimetic mode and narrativity exclude each other. But even if we put the non-existent base in ancient philosophy aside, ${ }^{12}$ the opposition between telling and showing or narration and imitation appears problematic as soon as one takes a closer look at how discussions of narrativity make use of it. Genette, for instance, explained in a letter to Gaudreault his view that plays and movies do not narrate their stories as follows:

11 These circumstances taken into account, Genette's (1966) objection to Plato that the representation of direct speech is not an imitation but merely a "quotation" appears unjustified, since in oral presentations (which Plato had in mind) the poet can very well imitate the pitch of the voice, intonation, gestures and facial expressions of the characters (cf. Gaudreault 1988, 53-70).

12 For Aristotle, who in his Poetics (335 BC) conceptualises diegesis-contrary to Plato-as a subcategory of mimesis, the two notions are also not in opposition. 
[T]here is, for me, no such thing as theatrical or film narrative. The theatre does not recount, it "reconstitutes" a story upon the stage, and cinema likewise shows on the screen a story which it has "reconstituted" (in fact constituted, of course) on the set. (Genette quoted in Gaudreault 2009 [1988], 170) $)^{13}$

Taken literally, this assertion implies that the story already exists on the stage or movie set, and simply has to be shown to the audience either by way of a live performance or an audio-visual recording. As I have mentioned earlier, it does not make sense to assume that the story has any physical existence before and outside the perception and imagination of the spectators. If by showing we mean to present en bloc something existing independently from the spectators, the term can definitely not be applied to stories. On the level of single actions, objects or characters, the term might be used, but only figuratively if we are dealing with fictional stories. Strictly speaking, theatre performances and films only show what really happens on stage and what really happened in front of the camera.

The notion that stories can be "imitated" is even more problematic. Actors can imitate the gestures, mimicry and speech of other persons. In a metaphorical sense, we might say that they imitate fictional characters. But how can a play or film imitate a story? Interestingly enough, speaking of the filmic mode of presentation, Genette not only claims that the story already exists on the screen, but even before that on the film set. If the whole postproduction with processes such as editing and sound design is reduced to showing a story that fundamentally already exists, crucial aspects of film composition are simply ignored.

\section{Schmid's Model of Narrative Constitution}

In order to substantiate my claim that the filmic and theatrical modes of presenting stories are only marginally related to the activities of showing or imitating, I would like to introduce Wolf Schmid's ideal-type genetic model of narrative constitution (2010 [2005], 190-215). Schmid's model proposes to expand the common opposition between story and narrative to four levels: happenings, story, narrative and the presentation of the narrative. The story is the result of a selection of specific characters and actions from an infinite number of possible happenings, and the attribution of specific qualities to these elements. The narrative is the result of the composition of the selected elements (for instance, the re-ordering of

13 I have slightly altered the translation given in Gaudreault (2009), since in the present context it is essential to translate "histoire" as "story" and not as "narrative." 
their time sequence). And the presentation of the narrative implies transmission by verbal language in literature, by audio-visual means in film and by way of live performance in the theatre. Thus media-specific operations only come into play on this "last" level of the model ("last" being used metaphorically here, since Schmid's model is an ideal type).

On which level are activities of showing or imitating to be located? Neither the selection of specific actions and qualities nor the composition of these elements into a specific arrangement are operations having anything to do with these activities. Only in the "last" step of presenting the narrative do they play a certain part, but even here a minor one since, as I have argued earlier, the filmand theatre-specific discourses and modes of presentation involve much more than imitating persons and showing single actions or objects.

Betrayal is again a good example to illustrate this. The reversal of the order in which the events are presented is a procedure pertaining to the transition from story to narrative, and not to the media-specific transition from the narrative to the presentation of the narrative. And this procedure is of course based on a "prior" selection of events from the amorphous mass of happenings. Talking about works of literary fiction, Schmid presupposes a narrator for these kinds of procedures, even in cases of heterodiegetic, extradiegetic and what Chatman has called "covert" narration.

Thus an asymmetry appears in Schmid's reasoning. Discussing narrativity, he claims that only literary narration is characterized by mediacy and the presence of a narrative instance, while film and drama directly show their stories. In his model of narrative constitution, on the other hand, media-specific modes of presentation (such as the mimetic mode) only play a part in the "last" of three steps of transformation. And Schmid does not explain why, in the case of film and drama, the procedures on the "first" two levels should not establish mediacy and a narrative instance, while in literature they do so even in cases of covert narration. Metaphorically speaking, "between" story and recipient not only the conversion of "raw" elements (actions and qualities) into the specific "language" of the given medium has to be accounted for, but also the composition of selected actions, such as the reversal of chronological order in Betrayal. This shows that a story simply cannot exist without narrative mediation.

Concerning drama and film, positions 1 and 2 usually ascribe procedures pertaining to the composition of selected actions simply to real authors, while for literary works a fictional narrator is given the same credit even in cases where he acts 
"covertly" (in Chatman's sense) and therefore can only be inferred. ${ }^{14}$ Resistance against acknowledging a narrative instance in film or drama is thus neither sufficiently explained by its compositional function or force (which on two of three levels is equivalent to that in literature) nor by its manifest perceptibility (which in literature may be just as implicit as in film and drama). Rather, a widespread refusal to accept impersonal, non-human instances of narrative agency seems to be decisive. This view explains the irritating fact that authors like Schmid (2010 [2005], 1-7) or Wolf $(2002,47)$ use "narrator" and "narrative instance" as interchangeable synonyms, without giving any justification for restricting the latter term to verbal narration (which one would expect from position-2 theorists who allow for nonverbal forms of narration).

To call upon real authors at this level of narratological abstraction is inadvisable, or else it would also have to be done for literary texts, which would amount to equating narrators who are both hetero- and extradiegetic with the real authors. Still, the problem would not be solved but only relocated, since the consequence would be to simply shift the function of narrative agent to real authors. ${ }^{15}$

There are further inconsistencies that positions 1 and 2 suffer from. For instance, that theorists like Genette speak of "récit" and "histoire" as the semiological pair signifier/signified (1980 [1972], 27) while at the same time assuming that there can be stories without narration is tantamount to claiming that there can be represented objects without a corresponding representation. Or the poor reasoning of position 2 which concedes that film and theatre narrate their stories but refuses to call the instance responsible for this activity "narrative instance."

Apart from mediacy, presence of a narrative instance and absence of mimesis, writers inclined to position 2 occasionally bring up other aspects. Wolf (2002, 52-53, 95) and Ryan (2004, 10-11, 15), for instance, both maintain that literature possesses a higher degree of narrativity than film and drama because it is able to convey causal relations and temporal connections more explicitly. The higher degree of narrativity is justified by the "lower degree of narrativisation necessary on the part of the recipient" (Wolf 2002, 95; translation mine). It may be true that novels and short stories, by means of their verbal narrators, often make use of

14 Genette is the only theorist mentioned here for whom the literary narrator in these cases coincides with the author (1980 [1972], 249).

15 In this context it is important not to confound the following two questions: 1) does it make sense in the case of narrations without explicit narrators to assume a virtual narrative agency distinct from real authors?; 2) are nonverbal presentations of stories to be considered as narrative (and if so, in a broad or narrow sense)? David Bordwell's stance (1993 [1985], 61-62; 2008, 121-133) shows that it is possible to answer the first question in the negative and the second in the affirmative. 
more explicit propositions. But first of all, they do not have to do so, and second, film and drama, besides also being able to use verbal narrators, have their own (conventionalised) means of making temporal and causal relations explicit. Moreover, why should a higher degree of (mostly schematic) implication on the part of the recipient determine a lower degree of narrativity in the first place ${ }^{16}$

\section{Narrator Figures and the Basic Narrativity of Drama}

After this general criticism of positions 1 and $2,{ }^{17}$ I would now like to focus on positions $3 \mathrm{a} / \mathrm{b}$ and 4 . Concerning $3 \mathrm{a}$ and $\mathrm{b}$, I can be brief, since insofar as these conceptions correspond to 2, I have already stated my objections; and to the extent that they correspond to 4, they will be discussed shortly. The remaining questions are: if one accepts that mimesis and diegesis are not simple oppositions and that mediacy and narrative agency are not appropriate criteria for distinguishing between literary and filmic/dramatic narration, does it still make sense to differentiate between a narrow and a broad definition of narrativity? And should film, with its many expressive possibilities (editing, camera movements, sound design, etc.), not be attributed a higher degree of narrativity than drama? My answer to the first question is: I do not think so. Concerning the second question, I agree that film narration can much more easily "disrupt the chronology of the story [...] stretch or concentrate time [...] and change the perspective of the presentation" (Pfister 1991 [1977], 24; cf. section 4 above) than theatrical narration, which appears more restricted in these respects. However, that a drama should not at all be capable of these procedures can easily be disproved, for instance by the already mentioned play Betrayal, a perfect example of the disruption of linear chronology. That the conventional unities of time, place and action have traditionally prevented this potential from being exploited more fully does not alter the fact that it has always been available (cf. Diezel 1999, 55-56).

16 If the cognitive effort on the recipient's part should really be decisive here, then, conversely, the ostensible immediacy of filmic and dramatic presentations would have to raise their narrativity.

17 My criticism of theorists such as Genette, Schmid, Prince, Wolf or Ryan only pertains to the issues explicitly referred to, especially considering that the latter two have contributed substantially to the transmedial extension of literary narratology. 
This leads me to conclude that only position 4 stands the test of rigour of argument and logical consistency. There is one point, though, that still needs to be clarified. Literary and theatre scholars opposing the notion that plays are less narrative than novels often point to a trend in modern drama to include more and more narrative elements in their performances, such as prologues and epilogues or comments by stage managers and other overt narrator figures (cf. Nünning and Sommer 2008).$^{18}$ However, if we really want to attribute full narrativity to drama, we have to be careful to put these elements in their proper places, since the basic narrativity of drama does not in the least depend on them. A dramatic narrative instance responsible for selection, arrangement and focalisation can and should be construed without direct recourse to these narrative elements. Rajewsky (who advocates position 2) rightly finds fault with Jahn who confounds this basic kind of narrative instance with the position occupied by narrator figures who appear on stage. In his analysis of Shakespeare's Pericles, Jahn writes:

Introducing himself as a narrator figure on the communicative level of fictional mediation, Gower exerts an uncommon amount of [...] "conative solicitude": he addresses the audience, [...] advertises the story's didactic purpose [...], adds some verbal decor which establishes story-HERE and story-NOW, and finally asks the spectators to see and judge for themselves. Later in the play, Gower reappears as a perceptive moderator who introduces each of the remaining acts and eventually speaks the epilogue, closing the play's mediating frame. As long as he is physically present, he is an overt narrator, and in the scenes in which he is physically absent, he is the behind-the-scene shower-agency in control of selection, arrangement, and presentation. Basically, then, an "absolute drama" (Pfister's default type of play) is like [...] Pericles without the figure of Gower but not without the function of Gower. (Jahn 2001, 671; original emphasis)

According to this analysis, a narrator figure may wholly incorporate the function of the basic narrative instance responsible for the overall design of the play, even if the presence of this narrator figure alternates between an explicit and implicit presence on stage. This opinion is even more clearly stated in the following passage:

All narrative genres are structurally mediated by a first-degree narrative agency which, in a performance, may either take the totally unmetaphorical shape of a vocally and bodily present narrator figure [...] or remain an anonymous and impersonal narrative function in charge of selection, arrangement, and focalization. (Jahn 2001, 674)

18 Kuhn (position 3a), despite considering drama as narrative in a broad sense only, also points to epic components of this kind and concedes that "Drama [...] may contain elements and segments which can also be classified as narrative in a narrow sense" (2012, 74; translation mine). 
I would object to this view that we are not facing an either-or alternative here. The vocally and bodily present narrator figure-an optional ingredient-can never occupy the position of the impersonal narrative instance, which is always there and which is also responsible for presenting the narrator figure to us in the first place. ${ }^{19}$ And while narrator figures (as fictional counterparts of human beings) use verbal language, the "language" of theatre and film is not (only) verbal.

\section{A New Definition of Narration}

I would like to conclude my discussion of comparisons between different media with a new definition of narration which makes the transformations in Schmid's model more explicit than existing definitions do. To narrate is an activity which necessarily involves the following processes (which are ideal-type in nature): selection of characters, actions and corresponding qualities from an infinite number of events; composition (temporal reordering and possibly linearization) of this selection; and presentation of this artificial array in a specific medium. Even minimalist definitions such as "representation of two events" imply all of these procedures, since without selection there are no events, without composition there is no sequence in which the events can be presented, and without presentation in the "language" of a specific medium there is no narrative to be perceived by the recipients.

This indicates that stories (which in Schmid's model correspond to the selected actions and their qualities) never reach recipients directly; that to narrate in any medium entails activities of selection, arrangement and mediation which for practical reasons should be attributed to a narrative instance, be it personal (as in literature) or impersonal (as in film and theatre). To account for realisations in the different media, it suffices to distinguish between "verbal" (or "literary"), "audio-visual" (or "filmic") and "dramatic" narration, a terminology which, for its simplicity and comprehensibility, is preferable to distinctions such as "narrative" versus "mediated" (Schmid 2010 [2005], 7) or to "convey" versus to "realise" stories (Wolf 2002, 42; translation mine) or to "telling” versus "showing."

Rajewsky has complained about a trend in narratology to overstress common features of different media at the cost of ignoring their specificity. To assume a

19 In film theory, this difference in hierarchy between the basic narrative instance and narrator figures or character narrators, no matter how remarkable their contribution and how much they themselves pretend to be responsible, has long been established (cf. Gaudreault and Jost 1990, 49-56). 
narrative instance for nonverbal media is, for Rajewsky, an example of this trend and highly problematic, since it means raising traditional definitions of verbal storytelling to foundational categories of a transmedial narratology (2007, 30 and 50). From what I have presented in this paper, it can easily be guessed that my position is diametrically opposed to Rajewsky's. The problem is not that differences between media are ignored, but rather that universal principles of narrativity (such as narration necessarily and always implying mediacy) are claimed by some authors to be distinctive features of verbal narration only (while the same authors leave unexplained how exactly narration in nonverbal media should work without mediation).

To conclude, a short note to prevent misunderstandings is in place. In my opinion, the differences between verbal, audio-visual and dramatic forms of narration are significant. It is the task of a transmedial narratology to analyse them in detail. But I also think that the real differences can only be examined against the background of an unbiased assessment of basic similarities, some of which I have tried to clarify in this paper.

\section{Works Cited}

Abbott, H. Porter. 2014 [2009]. “Narrativity.” In Hühn et al., eds., 567-607. Also available at: http://www.lhn.uni-hamburg.de/article/narrativity (Revised 20 January 2014)

Alber, Jan, and Monica Fludernik. 2014 [2009]. “Mediacy and Narrative Mediation.” In Hühn et al. eds., vol. 1: 310-325. Also available at: http://www.lhn.uni-hamburg.de/article/ mediacy-and-narrative-mediation (Revised 22 April 2014)

Aristotle. 2013 [335 BC]. Poetics. Translated by Anthony Kenny. Oxford: Oxford University Press. Barthes, Roland. 1966. "Introduction à l'analyse structurale des récits." Communications 8: 1-27.

Bordwell, David. 1993 [1985]. Narration in the Fiction Film. London: Routledge.

Bordwell, David. 2008. Poetics of Cinema. New York: Routledge.

Bremond, Claude. 1964. "Le message narratif." Communications 4: 4-32.

Brütsch, Matthias. 2013a. "Ist Erzählen graduierbar? Zur Problematik transmedialer Narrativitätsvergleiche.” Diegesis: Interdisziplinäres E-Journal für Erzählforschung / Interdisciplinary E-Journal for Narrative Research 2.1: 54-74.

Brütsch, Matthias. 2013b. "When the Past Lies Ahead and the Future Lags Behind: Backward Narration in Film, Television, and Literature." In (Dis)Orienting Media and Narrative Mazes, edited by Julia Eckel et al., 293-312. Bielefeld: Transcript.

Chatman, Seymour. 1978. Story and Discourse: Narrative Structure in Fiction and Film. Ithaca, NY: Cornell University Press.

Chatman, Seymour. 1990. Coming to Terms: The Rhetoric of Narrative in Fiction and Film. Ithaca, NY: Cornell University Press. 
Diezel, Peter. 1999. “Narrativik und die Polyphonie des Theaters.” In Die erzählerische Dimension: Eine Gemeinsamkeit der Künste, edited by Eberhard Lämmert, 53-71. Berlin: Akademie Verlag.

Friedemann, Käte. 1910. Die Rolle des Erzählers in der Epik. Leipzig: Haessel.

Gaudreault, André, and François Jost. 1990. Le récit cinématographique. Paris: Nathan.

Gaudreault, André. 1988. Du littéraire au filmique: système du récit. Paris: Méridiens Klincksieck.

Gaudreault, André. 1990. “Les aventures d'un concept: la narrativité.” In Christan Metz et la théorie du cinéma, edited by Michel Marie and Marc Vernet, 121-131. Paris: Meridien Klincksieck.

Gaudreault, André. 2009. From Plato to Lumière: Narration and Monstration in Literature and Cinema. Translated by Timothy Barnard. Toronto: University of Toronto Press (originally published as Gaudreault 1988).

Genette, Gérard. 1966. "Frontières du récit.” Communications 8: 152-163.

Genette, Gérard. 1980 [1972]. Narrative Discourse: An Essay in Method. Translated by Jane E. Lewin. Ithaca, NY: Cornell University Press.

Genette, Gérard. 1988 [1983]. Narrative Discourse Revisited. Translated by Jane E. Lewin. Ithaca, NY: Cornell University Press.

Hamburger, Käte. 1994 [1957]. Die Logik der Dichtung. 4th edition. Stuttgart: Klett-Cotta.

Herman, David, ed. 2007. The Cambridge Companion to Narrative. Cambridge: Cambridge University Press.

Hühn, Peter, Jan Christoph Meister, John Pier and Wolf Schmid, eds. 2014 [2009]. Handbook of Narratology. 2nd edition, 2 volumes. Berlin and Boston: De Gruyter. Available online as the living handbook of narratology at: http://www.lhn.uni-hamburg.de/

Jahn, Manfred. 2001. "Narrative Voice and Agency in Drama: Aspects of a Narratology of Drama." New Literary History 32 (3): 659-679.

Kuhn, Markus. 2012. "Narrativität transmedial: Von der sprachbasierten zur audiovisuellen Narratologie. Überlegungen zur medialen Reichweite der Narrativität und den Grundlagen einer audiovisuellen Filmnarratologie." In Film, Text, Kultur: Beiträge zur Textualität des Films, edited by John A. Bateman et al., 58-85. Marburg: Schüren.

Laffay, Albert. 1948. “Le récit, le monde, et le cinéma.” Les temps modernes 20 (21): 1361-1375, 1579-1600.

Laffay, Albert. 1964. Logique du cinéma: création et spectacle. Paris: Masson.

Lubbock, Percy. 1924 [1921]. The Craft of Fiction. London: Jonathan Cape.

Mahler, Andreas. 2001. "Erzählt der Film?” Zeitschrift für französische Sprache und Literatur 111 (3): 260-269.

Metz, Christian. 1968a [1964]. “Le cinéma: langue ou langage?” In C. M. Essais sur la signification au cinéma, vol. 1, 39-93. Paris: Klincksieck.

Metz, Christian. 1968b [1966]. "Le cinéma moderne et la narrativité." In C. M. Essais sur la signification au cinéma, vol. 1, 185-221. Paris: Klincksieck.

Metz, Christian. 1968c [1966]. "Remarques pour une phénoménologie du Narratif.” In C. M. Essais sur la signification au cinéma, vol. 1, 25-35. Paris: Klincksieck.

Nünning, Ansgar, and Roy Sommer. 2008. "Diegetic and Mimetic Narrativity: Some further Steps towards a Narratology of Drama." In Pier and García Landa, eds., 331-354.

Nünning, Ansgar, and Vera Nünning. 2002. "Produktive Grenzüberschreitungen: Transgenerische, intermediale und interdisziplinäre Ansätze in der Erzähltheorie.” In Nünning and Nünning, eds., 1-22. 
Nünning, Ansgar, and Vera Nünning, eds. 2002. Erzähltheorie transgenerisch, intermedial, interdisziplinär. Trier: Wissenschaftlicher Verlag Trier.

Pfister, Manfred. 1993 [1977]. The Theory and Analysis of Drama. Translated by John Halliday. Cambridge: Cambridge University Press.

Pier, John, and José Ángel García Landa, eds. 2008. Theorizing Narrativity. Berlin and New York: Walter de Gruyter.

Plato. 2008 [ca. 370 BC]. Republic. Translated by Robin Waterfield. Oxford: Oxford University Press.

Prince, Gerald. 1982. Narratology: The Form and Function of Narrative. Berlin: Mouton.

Prince, Gerald. 1987. A Dictionary of Narratology. Lincoln: University of Nebraska Press.

Prince, Gerald. 1996. "Remarks on Narrativity." In Perspectives on Narratology: Papers from the Stockholm Symposium on Narratology, edited by Claes Wahlin, 95-106. Frankfurt a. M.: Peter Lang.

Prince, Gerald. 1999. “Revisiting Narrativity.” In: Grenzüberschreitungen: Narratologie im Kontext / Transcending Boundaries: Narratology in Context, edited by Walter Grünzweig and Andreas Solbach, 43-51. Tübingen: Gunter Narr.

Prince, Gerald. 2008. “Narrativehood, Narrativeness, Narrativity, Narratability." In Pier and García Landa, eds., 19-27.

Rajewsky, Irina 0. 2007. “Von Erzählern, die (nichts) vermitteln: Überlegungen zu grundlegenden Annahmen der Dramentheorie im Kontext einer transmedialen Narratologie." Zeitschrift für französische Sprache und Literatur 117 (1): 25-68.

Richardson, Brian. 2007. "Drama and Narrative." In Herman, ed., 142-155.

Ryan, Marie-Laure. 2004. “Introduction.” In Narrative Across Media: The Languages of Storytelling, edited by M. L.-R., 1-40. Lincoln: University of Nebraska Press.

Ryan, Marie-Laure. 2005. “On the Theoretical Foundations of Transmedial Narratology.” In Narratology beyond Literary Criticism: Mediality, Disciplinarity, edited by Jan Christoph Meister, 1-23. Berlin and New York: Walter de Gruyter.

Ryan, Marie-Laure. 2007. “Toward a Definition of Narrative.” In Herman, ed., 22-35.

Ryan, Marie-Laure.2014 [2009]. “Narration in Various Media.” In Hühn et al., eds., vol. 1: 468-488. Also available at: http://www.lhn.uni-hamburg.de/article/narrationvarious-media (Revised 7 October 2014)

Schmid, Wolf. 2010 [2005]. Narratology: An Introduction. Translated by Alexander Starritt. Berlin and New York: De Gruyter.

Spielhagen, Friedrich. 1967 [1883]. Beiträge zur Theorie und Technik des Romans. Reprint. Göttingen: Vandenhoeck \& Ruprecht.

Stanzel, Franz K. 1995 [1979]. Theorie des Erzählens. 6th ed. Göttingen: Vandenhoeck \& Ruprecht.

Stanzel, Franz K. 1986 [1979]. A Theory of Narrative. Translated by Charlotte Goedsche. Cambridge: Cambridge University Press.

Todorov, Tzvetan. 1966. “Les catégories du récit littéraire.” Communications 8: 125-151.

Wolf, Werner. 2002. "Das Problem der Narrativität in Literatur, bildender Kunst und Musik: Ein Beitrag zu einer intermedialen Erzähltheorie.” In Nünning and Nünning, eds., 23-104.

Wolf, Werner. 2011. "Narratology and Media(lity): The Transmedial Expansion of a Literary Discipline and Possible Consequences." In Current Trends in Narratology, edited by Greta Olson, 145-180. Berlin and New York: De Gruyter. 